\title{
Introduction
}

\section{Detaining the Displaced}

\author{
EleAnor Acer
}

$\mathrm{O}$ ver the last few years, the public has become increasingly aware of the fact that many asylum seekers are imprisoned by the very states they flee to in search of protection. In February 2002, Australian citizens, including members of church and community groups, organized demonstrations to protest the Australian government's policy of mandatory detention. ${ }^{1}$ Earlier this year about 240 mostly Afghan asylum seekers at Australia's infamous Woomera detention centre staged a two-week hunger-strike to protest their treatment and a group of Iraqi asylum seekers reportedly dug their own graves to protest their imprisonment in Woomera. ${ }^{2}$ In the U.S., religious leaders publicly criticized the U.S.'s mandatory detention of arriving asylum seekers, and the press and human rights groups have criticized the U.S.'s detention of children citing, most recently, the detention of a disabled teenage asylum seeker from Guinea in adult criminal jails for over a year. ${ }^{3}$

In the wake of the September 11 attacks in New York and Washington, D.C., some countries have proposed or passed harsh new laws that call for the increased detention of non-citizens. The anti-immigrant rhetoric in many countries has escalated, at times targeting individuals of Arab or Muslim background. Asylum seekers, often the victims of human rights abuses themselves, are more vulnerable than ever in the current climate.

The Executive Committee of UNHCR, in Conclusion 44, has denounced the arbitrary detention of asylum seekers, stressing that detention should normally be avoided and should only be resorted to when necessary and on grounds prescribed by law. This is hardly a surprise given the Refugee Convention's prohibitions against restricting refugees' movements and the prohibitions against arbitrary detention under the International Covenant on Civil and Political Rights (the ICCPR).

In February 1999, the UNHCR issued its Revised Guidelines on Applicable Criteria and Standards Relating to the
Detention of Asylum Seekers (the UNHCR Detention Guidelines). The UNHCR Detention Guidelines affirm that "[a]s a general rule, asylum seekers should not be detained," and that "the use of detention is, in many instances, contrary to the norms and principles of international law." Urging a "presumption against detention," the UNHCR Detention Guidelines state that "viable alternatives to detention ... should be applied first unless there is evidence to suggest that such an alternative would not be effective in an individual case." When a decision to detain is made, the Detention Guidelines recommend that such a decision "only be imposed in a non-discriminatory manner for a minimal period" and that procedural guarantees be provided for, including "automatic review before a judicial or administrative body independent of the detaining authorities" and subsequent "regular periodic reviews of the necessity for the continuance of detention."

Some states aspire to meet their obligations under international law and standards. Others do not. The articles in this volume of Refuge, as well as one article to follow in Volume 20.4, examine the detention practices of a number of different states - closely examining the mandatory detention regimes of Australia and the United States, as well as the detention practices of Canada, Mexico, and South Africa. Some of these articles address the impact of detention on vulnerable populations, including children and survivors of torture. The articles also highlight the impact of post-September 11 security concerns on the debate over detention of asylum seekers and on the detention of individual asylum seekers.

As detailed in Jaya Ramji's article on South Africa's detention system, South African law relating to the detention of asylum seekers strives to meet that state's obligations under international law. But the law's high aspirations "on paper" are not met "in practice." One striking example concerns South African law's provision of automatic review of detention of asylum seekers by a judge of its High Court. 
As Ramji describes, "this review provision is rarely followed in practice" and this safeguard is further undermined by the failure of South African officials to provide notice of judicial review to detainees.

A survey that is being conducted on behalf of the Lawyers Committee for Human Rights by attorneys at a pro bono law firm has revealed that some states - and indeed most European states - do provide for, at least on paper, judicial review of detention decisions or other checks on arbitrary detention such as limits on the length of detention or periodic review of detention determinations. ${ }^{6}$ In Germany, for instance, detention determinations are made by the courts, and are subject to judicial review; there is no provision, however, for periodic review of detention determinations. In the Netherlands, the law provides for automatic review of decisions to detain asylum seekers by a district court, though it also does not provide for periodic review of detention determinations. Yet in the wake of September 11, even limited safeguards against arbitrary detention may be at risk, a concern raised by the United Kingdom's proposal to repeal automatic bail hearings for asylum seekers.

The detention practices of other states, including Australia and the United States, fall significantly short of international law and standards. In "'Between a Rock and a Hard Place': - Australia's Mandatory Detention of Asylum Seekers," Francesco P. Motta provides a comprehensive examination of Australia's mandatory detention policy and concludes that the policy puts Australia in breach of it obligations under international law. As Motta explains, " $\mathrm{t}$ ] he fact that Australia's detention policy is mandatory with no discretion not to apply it to an individual, irrespective of the circumstances, and given there is no recourse by a detained individual to judicial review of that detention, means ipso facto that it result in arbitrary detention." Australia, Motta concludes, has no intention of changing its mandatory detention policy - even though the justification for the policy is flawed and the costs of the policy are too high, leaving asylum seekers literally and figuratively "between a rock and a hard place."

The U.S. detention system for asylum seekers also falls far short of the requirements of international law and standards. As detailed in "Living up to America's Values: Reforming the U.S. Detention System for Asylum Seekers," decisions to detain asylum seekers who arrive without proper documentation are automatic under U.S. law. These detention determinations are made by the U.S. Immigration and Naturalization Service, rather than an independent entity, and the law does not provide for review of these determinations by an independent or judicial authority. In the wake of September 11, asylum seekers in the U.S. have faced additional hurdles, including reports of dis- criminatory parole denials. The U.S. detention system can be reformed, the author concludes in "Living up to America's Values." The article details the reforms that can be instituted - including the passage of legislation that would provide significant safeguards for asylum seekers - to ensure that U.S. detention procedures are consistent with international law and U.S. values of fairness.

The United States, in contrast to Australia, has at least begun to examine the use of alternatives to detention. In fact, the U.S. government tested a supervised release project, run by the Vera Institute of Justice, which achieved very successful results in terms of high appearance rates and cost savings. (This project is described in "Living up to America's Values.”) The U.S., however, despite this successful pilot project, has not instituted nationwide alternatives to detention. And the Australian government, as Motta notes in his article, has rejected proposals advancing the use of alternatives to detention.

As new states ratify the Refugee Convention and struggle to create fair asylum systems, they will have the opportunity to reject practices that are inconsistent with international law and instead embrace "best practices" that are consistent with their international obligations. Mexico is one state that stands at a critical crossroads, as pointed out by Gretchen Kuhner, in her article "Detention of Asylum-seekers in Mexico." Mexico ratified the Refugee Convention and the Protocol in April 2000, and in March 2002 began implementing its own adjudication system for asylum claims rather than relying on UNHCR to make eligibility determinations. In Mexico, asylum seekers who were detained by Mexican authorities and had not yet submitted applications to UNHCR were regularly transferred to a detention center in Mexico City where they typically remained for months, held in conditions that have been criticized by local advocates. Kuhner points out that the Mexican government will now have an opportunity to create a new detention policy.

Unfortunately, it is often the most vulnerable who suffer most from the trauma of detention. This fact is increasingly difficult for states to ignore as medical professionals around the world are documenting the impact of detention on survivors of torture, rape, and the other traumatic experiences that refugees typically suffer. ${ }^{7}$ The detention of children is particularly problematic, and the effect of detention on a child is acute. In his piece, "Seeking Freedom, a Child Finds Himself behind Bars," Leonard S. Glickman profiles the story of a teenage asylum seeker who has been detained in the U.S. for over a year and a half. Through the story of this young Algerian asylum seeker, who was detained when he arrived in the U.S. at the age of sixteen to seek protection, Glickman identifies a number of serious problems in U.S. practices relating to children. The true tragedy though is the 
impact of detention on this child - a child who, Glickman reports, lives in detention with a sense of isolation and growing desolation.

The societal factors that contribute to negative stereotypes of asylum seekers are closely examined in Simon Philpott's article, "Protecting the Borderline and Minding the Bottom Line: Asylum Seekers and Politics in Contemporary Australia," to be published in the next issue of Refuge, Philpott traces Australian fears of "invasion" from colonial Australia, and details the ways in which current political leaders have advanced images of asylum seekers as "queue jumpers, illegals, [and] bogus refugees." This denigration of asylum seekers has fostered public hostility towards them, alleviating the government of responsibility toward asylum seekers and facilitating the privatization of detention in which "bottom-line considerations take precedence over concerns such as justice, dignity or rights." As Philpott emphasizes, "[s] uccessful denigration of asylum seekers as criminals and cheats not only enables the government to distance itself from their claims for consideration for residency in and citizenship of Australia, it brings the UN and the Refugee Convention into disrepute."

Even Canada, which, as Glynis Williams describes in her article "Detention in Canada: Are we on the Slippery Slope," often looks "good by comparison," may be on the "slippery slope" as it has recently adopted new legislation that may be used to detain more asylum seekers who arrive without identification - a situation facing many genuine refugees. Although the new law was proposed before September 11, Williams notes that "there is no doubt that anxiety regarding security has influenced the public debate." Williams underscores the impact of detention on the human rights of those detained in Canada and provides a vivid picture of the impact of detention through several short profiles of individual detainees, including a thirteenyear-old Congolese girl.

There is certainly a need to advance some solutions to this multi-faceted and complex problem. UNHCR, in the context of the global consultations, organized an expert roundtable to examine issues relating to Article 31 of the Refugee Convention, including detention. The expert roundtable, which met in November 2001, issued some summary conclusions, which included a recommendation that national legislation incorporate Article 31's standards and provide for judicial review of decisions to detain asylum seekers and urged that alternatives to detention should always be considered in individual cases. The experts recommended follow-up including "the preparation and dissemination of instructions to relevant levels of government and administration on the implementation of Article 31 ..."
The World Council of Churches, in co-operation with a wide range of non-governmental organizations, is planning to organize an International Consultation on Detention of Asylum Seekers in 2003. A detailed announcement relating to that Consultation is included in this volume. The Consultation will seek to bring together NGO representatives from all regions to take stock of current practices of detention and NGO strategies, and to develop and agree on a elements for a global strategy against detention.

In the end, however, it is states that must decide to respect their obligations under international refugee and human rights law. Only then will refugees find the protection that they have fled their homes to find. While it may be tempting for some states to sacrifice the human rights of refugees, whether in the name of "security," "national identity," or other national concerns, ignoring international law obligations seldom proves a constructive or effective response - let alone a response that is credible or legally appropriate.

\section{Notes}

1. John Shaw, "Australians Rally for Largest Protest Yet Over Refugee Policy," New York Times, 13 February 2002; “Australian Police Hunt Camp Escapees," BBC News, 30 March 2002.

2. Emma Tinkler, "Hunger Strike Ends at Camp," Montreal Gazette, 30 January 2002; Lindsey Arkley, "Afghan Asylum-seekers End Hunger Strike," USA Today, 31 January 2002; Patrick Barkham, "Refugees Dig Their Own Graves in Australian Detention," Guardian (London), 8 March 2002.

3. Esther Ibrahimian, Lutheran Immigration and Refugee Service, "Religious Leaders Decry Detention Conditions and Call for Changes," Detention Watch Network Newsletter, Summer 2001; Bishop Nicholas DiMarzio, Chairman of the U.S. Catholic Bishops' Committee on Migration, "Liberty (But Not) For All," Star Ledger, 24 May 2001; Leonard S. Glickman, President of the Hebrew Immigrant Aid Society, The Bergen County Record, 10 July 2001; Alan Elsner, "INS Removes Disabled Guinea Youth from Adult Jail," Reuters, 10 April 2002; "U.S Weighs Fate of Children Immigrants," New York Times, 27 March 2002.

4. United Nations High Commissioner for Refugees, Guidelines on Applicable Criteria and Standards relating to the Detention of Asylum-Seekers, February 1999. The Guidelines urge that exceptions to this general rule (protection of national security and public order, verification of identity, identification of basis of claim in a preliminary interview, destruction of documents/use of fraudulent documents to mislead) be clearly prescribed by national law in conformity with principles of international law.

5. Ibid.

6. The survey is being conducted by pro bono attorneys at the law firm of Debevoise \& Plimpton. 
7. See D. Silove, Z. Steel, and R. Mollica, "Detention of Asylum Seekers: Assault on Health, Human Rights, and Social Development," Lancet 357 (2001); see also Michele R. Pistone and Philip G. Schrag, "The New Asylum Rule: Improved but Still Unfair," Georgetown Immigration Law Journal 16 (Fall 2001): 49 , n. 272 \& n. 273 [citing numerous medical reports documenting that refugees often suffer from post-traumatic stress disorder, major depression, or other illnesses, including: Neal R. Holtan, "Survivors of Torture," Pub. Health Rep. 114 (1999): 489; Derrick Silove et al., "Anxiety, Depression and PTSD in Asylum-Seekers: Associations with Pre-Migration Trauma and Post-Migration Stressors," British J. Psychiatry 170 (1997): 351, 351-57; Hans Thulesium and Anders Hakansson, "Brief Report: Screening for Posstraumatic Stress Disorder Symptoms among Bosnian Refugees," J. Traumatic Stress 12 (1999): 167, 171-73 ]. A team of medical experts working with Physician for Human Rights is currently conducting a study of the impact of detention on asylum seekers who have been detained in the U.S. detention facilities.

Eleanor Acer is the Director of the Asylum Program at the Lawyers Committee for Human Rights (LCHR). She oversees the Lawyers Committee's pro bono asylum representation program, which provides hundreds of indigent refugees with volunteer legal representation every year, and advocates for the rights of refugees. She is also supervising LCHR's current survey of states' asylum detention procedures. She writes and speaks regularly on a range of refugee issues, including the detention of asylum seekers.

(C) Eleanor Acer, 2002. This open-access work is licensed under a Creative Commons Attribution-NonCommercial 4.0 International License, which permits use, reproduction and distribution in any medium for non-commercial purposes, provided the original author(s) are credited and the original publication in Refuge: Canada's Journal on Refugees is cited. 